
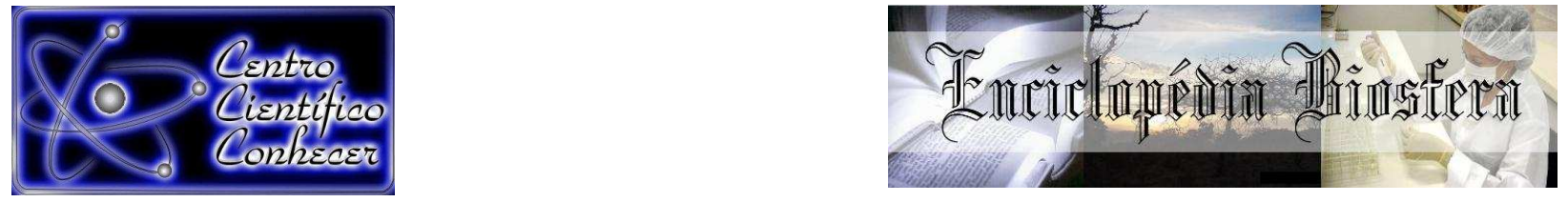

\title{
ESTABELECIMENTO DE PROTOCOLO DE EXTRAÇÃO DE DNA PARA Eugênia stipitata MC. VAUNG, VISANDO ESTUDOS MOLECULARES
}

Kelli Évelin Müller Zortéa ${ }^{1}$; Andréia Izabel Mikovski ${ }^{1}$; Rafaela Graziele Castrillon ${ }^{1}$; Danieli Aline Cigolini Ruzza²; Ana Aparecida Bandini Rossi ${ }^{3}$.

${ }^{1}$ Mestrandas do Programa de Pós-Graduação em Genética e Melhoramento de Plantas - PGMP / Universidade do Estado de Mato Grosso - UNEMAT. E-mail: kellimuller@hotmail.com

${ }^{2}$ Mestranda do Programa de Pós-Graduação em Biodiversidade e Agroecossistemas Amazônicos - PPGBioAgro / Universidade do Estado de Mato Grosso - UNEMAT.

${ }^{3}$ Doutora em Genética e Melhoramento de Plantas. Professora do Laboratório de Genética Vegetal e Biologia Molecular. Faculdade de Ciências Biológicas e Agrárias. PPGBioAgro; PGMP; PPGBioNorte - Universidade do Estado de Mato Grosso.

Recebido em: 03/10/2016 - Aprovado em: 21/11/2016 - Publicado em: 05/12/2016 DOl: 10.18677/EnciBio 2016B 045

\begin{abstract}
RESUMO
O araça-boi (Eugenia stipitata Mc. Vaung) é uma frutífera nativa da Amazônia, pertencente a família Myrtaceae. Sua polpa é consumida na forma de sucos, geleias e sorvetes devido ao aroma e sabor agradáveis. Estudos de diversidade genética através de técnicas moleculares vêm sendo cada vez mais utilizados, mas a primeira etapa é a obtenção de DNA íntegro por meio de técnicas adequadas de isolamento. Este trabalho objetivou estabelecer um protocolo de extração de DNA para Eugenia stipitata visando estudos moleculares. Foram coletadas folhas de E. stipitata, para isolamento do DNA. A extração de DNA foi com base no protocolo CTAB com modificações nas concentrações de CTAB (2 e 5\%), $\beta$-mercaptoetanol (0, 0,2 e 2 $\%)$, PVP (1 e $2 \%$ ) e presença e ausência de acetato de amônio (7,5 M). O DNA extraído foi amplificado com dois primers ISSR. A extração de DNA foi possível apenas com CTAB $5 \%$, a quantidade de $\beta$-mercaptoetanol interferiu na quantidade de DNA, sendo melhor nas concentrações maiores. Não houve diferenças significativas em relação a concentração de PVP e presença e ausência de acetato de amônio. Os dois primers ISSR amplificaram regiões do genoma de E. stipitata. A extração de DNA de E. stipitata deve ser realizada com CTAB $5 \%$ e $\beta$ mercaptoetanol a $2 \%$. O acetato de amônio pode ser retirado do protocolo sem prejuízo da qualidade do DNA. Os marcadores ISSR foram eficientes na amplificação e são recomendados para estudos de diversidade genética de $E$. stipitata.
\end{abstract}

PALAVRAS-CHAVE: Araça-boi, CTAB, Diversidade Genética. 


\title{
ESTABLISHMENT OF PROTOCOL FOR DNA EXTRACTION FOR Eugênia stipitata MC VAUNG, AIMING TO STUDIES WITH ISSR MARKER.
}

\begin{abstract}
The Araça-boi (Eugenia stipitata Mc. Vaung) is a native fruit of the Amazon, belonging to Myrtaceae family. Its pulp is consumed in the form of juices, jellies, ice cream because of the pleasant aroma and flavor. Studies of genetic diversity through molecular techniques are being increasingly used, but the first step is the obtaining of intact DNA by suitable isolation techniques. This study aimed to establish a DNA extraction protocol for Eugenia stipitata targeting molecular studies. Leaves were collected $E$. stipitata for DNA isolation.The extraction of DNA from the CTAB protocol changes in the concentrations of CTAB (2 and $5 \%), \beta$-mercaptoethanol $(0,0,2$ and $2 \%$ ), PVP (1 and $2 \%$ ) and presence and absence of ammonium acetate $(7,5 \mathrm{M})$. The extracted DNA was amplified with two primers ISSR. DNA extraction was only possible with CTAB 5\%, the amount of $\beta$-mercaptoethanol interferes with the amount of DNA, being best at higher concentrations. There were no significant differences in the concentration of PVP in the presence or absence of ammonium acetate. The two ISSR primers amplify regions of the genome of E. stipitata. E. stipitata DNA extraction should be performed with CTAB 5\% and $\beta$-mercaptoethanol $2 \%$. The ammonium acetate can be removed from the protocol without jeopardizing the quality of DNA. The ISSR markers were efficient in amplifying and are recommended for genetic diversity studies of E. stipitata.
\end{abstract}

KEYWORDS: Araça-boi, CTAB, Genetical Diversity.

\section{INTRODUÇÃO}

A família Myrtaceae possui aproximadamente 5.760 espécies e132 gêneros, sendo encontrados no Brasil 990 espécies e 23 gêneros (GOVAERTS et al., 2015; SOBRAL et al., 2015). A esta família pertencem espécies medicinais, ornamentais, lenhosas e de frutos comestíveis (JORGE et al., 2000).

O araça-boi (Eugenia stipitata Mc. Vaung), uma das espécies dessa família, é uma frutífera nativa da Amazônia e vem sendo cultivada em pequena escala no Peru, Bolívia, Equador, Colômbia e Brasil, seu fruto é uma baga globosa e a polpa por ser muito ácida não é consumida in natura, sendo consumida na forma de sucos, geleias e sorvetes devido ao aroma e sabor agradáveis (MACEDO \& TEIXEIRA, 2012).

Muitas espécies nativas, sem nem um grau de domesticação vem sendo estudadas, a fim de realizar o cultivo por meio da agricultura comercial levando essas espécies ao manejo sustentável e a conservação, que caracteriza-se por proporcionar o conhecimento do fluxo gênico, sistema reprodutivo e diversidade entre populações (ZUCCHI, 2002).

Estudos de diversidade genética por meio de técnicas moleculares vêm sendo cada vez mais utilizados. Segundo OLIVEIRA et al., (2007), a utilização da PCR (Reação em Cadeia da Polimerase), em estudos moleculares, permite a amplificação in vitro do genoma de qualquer indivíduo em regiões específicas, permitindo análises sobre a diversidade genética de populações e a obtenção de grande quantidade de DNA para sequenciamento.

Para realização de estudos moleculares, a primeira etapa é a obtenção de DNA íntegro e de boa qualidade por meio de metodologias adequadas de isolamento (DANNER et al., 2011; MELLO, et al., 2015), pois a qualidade do DNA é 
importante para produzir amostras puras suficientes para não inibir os tratamentos enzimáticos ou causar interferências nos padrões de amplificação e migração em gel de eletroforese (ROMANO \& BRASILEIRO, 1999). A maioria dos protocolos existentes é derivada do protocolo CTAB (Brometo de Cetil Trimetil Amônio) descrito por DOYLE \& DOYLE (1987), modificado de acordo com cada espécie (DEVI et al., 2013).

Não foram encontrados na literatura estudos com dados moleculares sobre $E$. stipitata. Portanto, este trabalho objetivou estabelecer um protocolo de extração e amplificação de DNA para a espécie visando estudos de diversidade genética com marcadores moleculares.

\section{Área de estudo e material vegetal}

\section{MATERIAL E MÉTODOS}

A pesquisa foi realizada no Laboratório de Biologia Molecular da Universidade do Estado de Mato Grosso, campus de Alta Floresta. O material vegetal utilizado consistiu em folhas em estágio intermediário coletadas de E. stipitata. A coleta foi realizada um dia antes da extração e o material vegetal foi armazenado em geladeira a $4^{\circ} \mathrm{C}$ até o momento do uso.

\section{Extração do DNA genômico}

O DNA genômico total foi extraído de aproximadamente $300 \mathrm{mg}$ de folhas, seguindo o método CTAB descrito por DOYLE \& DOYLE (1987) com alterações, conforme descrito na Tabela 1.

TABELA 1. Testes de extração de DNA em E. stipitata, partindo do protocolo CTAB descrito por DOYLE \& DOYLE (1987) com modificações.

\begin{tabular}{ccccc}
\hline Amostra & CTAB & PVP & $\boldsymbol{\beta}$-mercaptoetanol & $\begin{array}{c}\text { Acetato de } \\
\text { Amônio (7,5M) }\end{array}$ \\
\hline 1 & $2 \%$ & $1 \%$ & $0 \%$ & Ausente \\
2 & $2 \%$ & $1 \%$ & $0 \%$ & Presente \\
3 & $2 \%$ & $1 \%$ & $0,2 \%$ & Ausente \\
4 & $2 \%$ & $1 \%$ & $0,2 \%$ & Presente \\
5 & $2 \%$ & $1 \%$ & $2 \%$ & Ausente \\
6 & $2 \%$ & $1 \%$ & $2 \%$ & Presente \\
7 & $2 \%$ & $2 \%$ & $0 \%$ & Ausente \\
8 & $2 \%$ & $2 \%$ & $0 \%$ & Presente \\
9 & $2 \%$ & $2 \%$ & $0,2 \%$ & Ausente \\
10 & $2 \%$ & $2 \%$ & $0,2 \%$ & Presente \\
11 & $2 \%$ & $2 \%$ & $2 \%$ & Ausente \\
12 & $2 \%$ & $2 \%$ & $2 \%$ & Presente \\
13 & $5 \%$ & $1 \%$ & $0 \%$ & Ausente \\
14 & $5 \%$ & $1 \%$ & $0 \%$ & Presente \\
15 & $5 \%$ & $1 \%$ & $0,2 \%$ & Ausente \\
16 & $5 \%$ & $1 \%$ & $0,2 \%$ & Presente \\
17 & $5 \%$ & $1 \%$ & $2 \%$ & Ausente \\
18 & $5 \%$ & $1 \%$ & $2 \%$ & Presente \\
19 & $5 \%$ & $2 \%$ & $0 \%$ & Ausente \\
20 & $5 \%$ & $2 \%$ & $0 \%$ & Presente \\
21 & $5 \%$ & $2 \%$ & $0,2 \%$ & Ausente \\
22 & $5 \%$ & $2 \%$ & $0,2 \%$ & Presente \\
23 & $5 \%$ & $2 \%$ & $2 \%$ & Ausente \\
24 & $5 \%$ & $2 \%$ & $2 \%$ & Presente \\
\hline
\end{tabular}


O material vegetal foi macerado com a adição de nitrogênio líquido e transferido para microtubos, nos quais foram acrescentados $800 \mu \mathrm{L}$ de Tampão CTAB (100 mM Tris-HCl, pH 8,0; 1,4 M Cloreto de Sódio; 20 mM EDTA; CTAB e PVP), o $\beta$-mercaptoetanol foi adicionado separadamente. Essa etapa seguiu as concentrações descritas na Tabela 1. Os microtubos foram agitados por um minuto e incubados a $65^{\circ} \mathrm{C}$ por 40 minutos no banho-maria. Du rante a incubação a solução foi homogeneizada a cada 10 minutos. Em seguida os microtubos foram centrifugados a 10.000 rpm por 10 minutos, o sobrenadante foi transferido para um novo microtubo ao qual adicionou-se $700 \mu \mathrm{L}$ de clorofórmio:álcool isoamílico (24:1). Estes foram agitados em vórtex por aproximadamente 30 segundos e centrifugados por 10 minutos a $12.000 \mathrm{rpm}$. A fase aquosa superior foi transferida para um novo microtubo, adicionou-se então $500 \mu \mathrm{L}$ de isopropanol gelado misturando-se levemente. Adicionou-se 1/3 do volume de Acetado de Amônio (7,5 M) conforme Tabela 1. As amostras foram incubadas a $-20{ }^{\circ} \mathrm{C}$ por três horas.

Os microtubos foram centrifugados a $12.000 \mathrm{rpm}$ por 10 minutos, o líquido sobrenadante foi descartado. Foram realizadas três lavagens do precipitado sendo duas com etanol $70 \%$ e uma com etanol $95 \%$, os tubos foram centrifugados a $10.000 \mathrm{rpm}$ por três minutos a cada lavagem. Em seguida 0 material foi ressuspendido em $40 \mu \mathrm{L}$ de TE (10 mM Tris-HCl; $1 \mathrm{mM}$ EDTA) contendo RNAse em concentração de $40 \mu \mathrm{g} / \mathrm{ml}$ em cada microtubo. As amostras foram incubadas por mais 30 minutos a $35^{\circ} \mathrm{C}$ e levadas à geladeira a $4^{\circ} \mathrm{C}$ por 24 horas. Em seguida foram armazenadas a $-20^{\circ} \mathrm{C}$.

A qualidade e a concentração do DNA foram verificadas por eletroforese em gel de agarose 1\% e por comparação com marcador de DNA (50 e $100 \mathrm{ng} / \mu \mathrm{L}$ ). O gel foi corado com brometo de etídeo e fotografado com auxílio de transluminador.

\section{Teste de Amplificação via PCR}

Dois primers ISSR foram utilizados para o teste de amplificação: DiCA3'YG e DiGA3'RC. As reações foram realizadas em termociclador AerisTM (Esco®) com volume total de $15 \mu \mathrm{l}$ contendo: $1,5 \mu \mathrm{l}$ de Tampão 10X (10 mM Tris-HCl (pH 8,3); 50 mM Cloreto de Potássio; 0,1\% de tween 20), 1,5 $\mu$ l Cloreto de Magnésio (25mM), 3 $\mu \mathrm{l}$ de dNTPs $(1 \mathrm{mM}), 0,4 \mu \mathrm{l}$ formamida, $0,15 \mu \mathrm{l}$ de Taq polimerase $(5 \mathrm{U}), 1,5 \mu \mathrm{l}$ primer $(2 \mathrm{mM}), 2 \mu \mathrm{l}$ de DNA (10 $\mathrm{ng} / \mu \mathrm{l})$ e água destilada autoclavada para completar o volume.

O programa de amplificação compreendeu um ciclo inicial de desnaturação a $94{ }^{\circ} \mathrm{C}$ por quatro minutos, 37 ciclos de $94^{\circ} \mathrm{C}$ por um minuto, $58{ }^{\circ} \mathrm{C}$ por dois minutos e $72{ }^{\circ} \mathrm{C}$ por dois minutos e ciclo de extensão final de $72{ }^{\circ} \mathrm{C}$ por sete minutos conforme BRANDÃO (2008).

Após a reação as amostras foram submetidas à eletroforese em gel de agarose a 1,5\% em tampão de corrida TBE 1X (89,15 mM de Tris Base; 88,95 mM de Ácido Bórico e 2,23 mM EDTA) com voltagem de $80 \mathrm{~V}$ por cerca de cinco horas, para verificação dos produtos amplificados. $O$ gel foi corado com brometo de etídeo e fotografado sob luz ultravioleta.

\section{RESULTADOS E DISCUSSÃO}

A concentração de CTAB no tampão influenciou o resultado da extração de DNA para a espécie, pois o DNA de Eugenia stipitata foi extraído apenas com o tampão CTAB na concentração 5\% (Figura 1). Verificou-se que o DNA extraído era de boa qualidade, pois não ficou retido no poço e não apresentou arraste vertical. 
Esse resultado indica que não houve contaminação por polissacarídeos e nem degradação por DNAses. Resultados semelhantes para concentrações maiores de CTAB no tampão de extração (5\%) em relação a DOYLE \& DOYLE (1987) foram encontrados por SCHIMITT et al., (2014) em Curcuma longa, e SILVA et al., (2014) em Anarcadium giganteum.

O CTAB é um detergente utilizado para solubilizar as membranas e separar o DNA de polissacarídeos que podem tornar a amostra excessivamente viscosa (ROMANO \& BRASILEIRO, 1999). A presença de polissacarídeos geralmente é verificada com a retenção do DNA no poço, característica que não foi observada neste estudo.

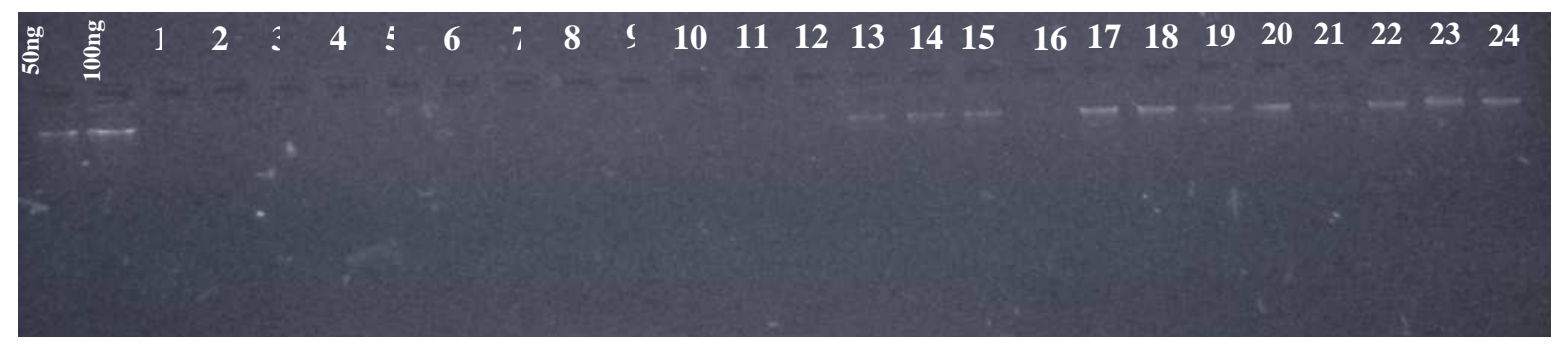

FIGURA 1. Gel de agarose 1\% com o DNA genômico de E. stipitata. 1 a 12 corresponde à extração com tampão CTAB $2 \% .13$ a 24 correspondem à extração com CTAB 5\%. Concentrações de PVP, $\beta$-mercaptoetanol e acetato de amônio conforme Tabela 1. $50 \mathrm{ng}$ (marcador de DNA ( de $50 \mathrm{ng} / \mu \mathrm{L}$ ) e $100 \mathrm{ng}$ (marcador de DNA ( de $100 \mathrm{ng} / \mu \mathrm{L}$ ). Fonte: ZORTÉA (2016).

As amostras sem $\beta$-mercaptoetanol (amostras 13, 14, 19 e 20; Figura 1) apresentaram menor quantidade de DNA se comparadas com as amostras com $2 \%$ de $\beta$-mercaptoetanol (amostras 17, 18, 23 e 24; Figura 1), demonstrando que a quantidade deste componente interferiu na quantidade de DNA extraído. Esse resultado está de acordo com o encontrado por SILVA (2010) para a extração de DNA de Eugenia dysenterica onde em concentrações acima de $1 \%$ de $\beta$ mercaptoetanol houve aumento da quantidade de DNA extraído. De acordo com a autora esse componente auxilia na descontaminação do DNA por compostos polifenólicos e dessa forma mantém o DNA mais íntegro.

O PVP também funciona como um antioxidante evitando a degradação do DNA por polifenóis, porém não houve alterações na quantidade e qualidade de DNA com o aumento desse componente, uma vez que não foram observados arrastes (Figura 1). PRIMIERI et al., (2013), extraíram DNA de Eugenia pyriformis com boa qualidade e quantidade significativa utilizando PVP em concentração de $2 \%$.

Não houve diferença em relação a quantidade e qualidade do DNA extraído de E. stipitata com a presença ou ausência de acetado de amônio (7,5 M) (Figura 1). O Acetado de Amônio é utilizado para purificar o DNA de polissacarídeos, quando há esse tipo de contaminação, é verificado no gel, DNA retido no poço (ROMANO \& BRASILEIRO, 1999). Como não foi observada essa característica em nenhuma amostra com ou sem esse componente, indica-se neste protocolo para $E$. stipitata que o acetado de amônio pode ser retirado do processo de extração sem alterar a quantidade e qualidade do DNA.

Para a amplificação do DNA com os dois marcadores ISSR foram utilizados os DNAs extraídos no protocolo com CTAB a $5 \%$ e concentrações diferentes de $\beta$ mercaptoetanol, PVP e acetato de amônio. Apenas os DNAs extraídos com os 
protocolos 13 e 21 não foram amplificados pelos dois primers ISSR testados (Figura 2).

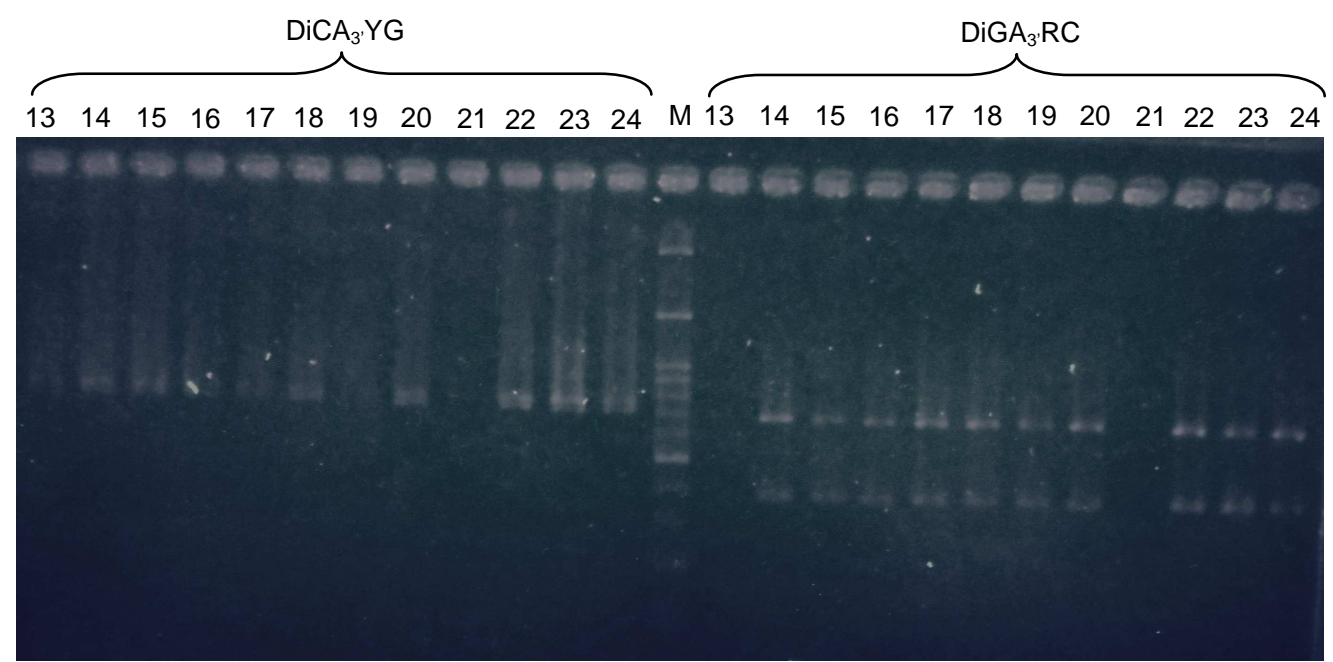

FIGURA 2. Gel de agarose $1,5 \%$ demonstrando o padrão de amplificação de 2 primers ISSR no DNA de E. stipitata extraído com diferentes protocolos. M: marcador 100 pb DNA ladder. Fonte: RUZZA (2016).

A amplificação do DNA com os primers ISSR indica que os protocolos de extração foram eficazes para o isolamento de DNA íntegro e livre de impurezas e que esses marcadores podem ser utilizados em estudos de diversidade genética da espécie.

\section{CONCLUSÃO}

A extração de DNA de E. stipitata foi possível apenas com tampão contendo CTAB a $5 \%$. Concentrações maiores de $\beta$-mercaptoetanol proporcionaram maior quantidade de DNA. A concentração de PVP não interferiu na integridade do DNA assim como o acetato de amônio, sendo possível utilizar menores concentrações de PVP e retirar o acetato de amônio sem prejuízo da qualidade do DNA extraído e diminuindo os custos e o tempo de extração.

O DNA extraído com o protocolo CTAB 5\% foi passível de amplificação pelos dois primers ISSR testados. Recomenda-se o uso do $\beta$-mercaptoetanol em concentração de $2 \%$ para a extração de DNA de E. stipitata, visando DNA de melhor qualidade para amplificação via marcadores moleculares.

Os resultados encontrados neste estudo sugerem que os marcadores ISSR podem ser utilizados em estudos de caracterização e análise de diversidade genética de E. stipitata, devido a amplificação ter sido eficiente.

\section{AGRADECIMENTOS}

A Universidade do Estado de Mato Grosso - UNEMAT pela oportunidade do curso de Mestrado em Genética e Melhoramento de Plantas.

\section{REFERÊNCIAS}

BRANDÃO, M. M. Diversidade genética de Myrcia splendens (SW.) DC (Myrtaceae) por marcadores ISSR em sistema corredor-fragmento semideciduais do Sul de Minas Gerais. 2008. 80 f. Dissertação (Mestrado em 
Engenharia Florestal) Universidade Federal de Lavras, Lavras, 2008. Disponível em < http://www.dcf.ufla.br/conservacao/dissertacoes/murilomalveira.pdf>.

DANNER, M. A; SASSO, S. A. Z.; BITTENCOURT, J. V. M.; CITADIN, I.; SACHET, M. R. Proposta de protocolo para extração de DNA de jabuticabeira. Ciência Florestal, v. 21, n. 2, p. 363-367, 2011. Disponível em < http://cascavel.ufsm.br/revistas/ojs-2.2.2/index.php/cienciaflorestal/article/view/3241>

DEVI, K. D.; PUNYARANI, K.; SINGH, N. S.; DEVI, H. S. An efficient protocol for total DNA extraction from the members of order Zingiberales- suitable for diverse PCR based downstream applications. SpringerPlus, v. 2, p. 669, 2013. Disponível em : < http://springerplus.springeropen.com/articles/10.1186/2193-1801-2-669>.DOI: 10.1186/2193-1801-2-669.

DOYLE, J. J; DOYLE, J. L. A rapid DNA isolation procedure for small amounts of fresh leaf tissue. Phytochemical Bulletin, v. 19, p.11-15, 1987.

GOVAERTS, R.; SOBRAL, M.; ASHTON, P.; BARRIE, F.; HOLST, B. K.; LANDRUM, L. R.; MATSUMOTO, K.; MAZINE, F. F.; NIC LUGHADHA, E.; PROENÇA, C.; SOARES-SILVA, L. H.; WILSON P. G.; LUCAS, E. World Checklist of Myrtaceae. Facilitated by the Royal Botanic Gardens, Kew. 2015. Disponível em $<$ http://www.kew.org/wcsp/> Acesso em 28 mar. 2015.

JORGE, L. I. F; AGUIAR, J. P. L.; SILVA, M. L. P.; Anatomia foliar de pedra-humecaá (Myrcia sphaerocarpa, Myrcia guianeses, Eugenia punicifolia - Myrtaceae). Acta Amazônica. v. 10, n. 1, p. 49-57, 2000. Disponível em: <http://www.scielo.br/pdf/aa/v30n1/1809-4392-aa-30-1-0049.pdf>.

MACEDO, S. T.; TEIXEIRA, P. C. Calagem e adubação fosfatada na formação de mudas de araçá-boi (Eugenia stipitata McVaugh). Acta Amazônica, v. 42, n. 3, p. 405-412, $2012 . \quad$ Disponível em: <http://www.periodicos.capes.gov.br/?option=com_pmetabusca\&mn=88\&smn=88\&ty pe $=$ m\&metalib=aHR0cDovL21 scGx1 cy5ob3N0ZWQuZXhsaWJyaXNncm91cC5jb20v cHJpbW9fbGlicmFyeS9saWJ3ZWIvYWN0aW9uL3NIYXJjaC5kbz9kc2NudD0wJmZy Ymc9JnNjcC5zY3BzPXByaW1vX2NIbnRyYWxfbXVsdGlwbGVfZmUmdGFiPWRIZm F1bHRfdGFiJmNOPXNIYXJjaCZtb2RIPUJhc2ljJmR1bT10cnVIJmluZHg9MSZmbj1zZ WFyY2gmdmlkPUNBUEVT\&buscaRapidaTermo=ra\%C3\%A7a+boi>

MELLO, L. M.; REINIGER, L. S.; MENEGHELLO, G. E.; VILLELA, F. A.; MOTA, M. S. Isolamento de DNA genômico a partir de folhas secas de Erythrina crista-galli $L$., FABACEAE (Corticeirado-banhado). Revista Thema, v. 12, n. 1, p.15-32, 2015. Disponível em < file://C:/Users/Usuario/Downloads/282-961-1-PB.pdf>

OLIVEIRA, M. C. S; REGINATO, L. C. A; ROESE, A. D; ANTHONISEN, D. G; PATROCÍNIO, E; PARMA, M. M; SCAGLIUSI, S. M. M; TIMÓTEO, W. H. B; JARDIM, S. N. Fundamentos teórico-práticos e protocolos de extração e de amplificação de DNA por meio da técnica de reação em cadeia da polimerase. São Carlos: Embrapa Pecuária Sudeste, p, 43. 2007. Dispon'vel em: < http://www.alice.cnptia.embrapa.br/bitstream/doc/48295/1/LivroProtMolecular.pdf>. 
PRIMIERI, S.; CARVALHO, M. A. L.; DALAGNOL, G. L.; DALLA COSTA, M..; JAEGER, J. P.; MAZO, J. C.; KOMATSU, R. A.; STROSCHEIN, M. R. D. Protocolo de extração de DNA para Uvaia (Eugenia pyriformis). Anais... Seminário de Pesquisa Extensão e Inovação do IFSC. 2013. Disponível em < http://eventoscientificos.ifsc.edu.br/index.php/sepei/sepei2013/paper/viewFile/191/30 $1>$.

ROMANO, E.; BRASILEIRO, A. C. M. Extração de DNA de plantas. Biotecnologia, Ciência e Desenvolvimento, Brasília, n. 9, p. 40-43, 1999. Disponível em <http://www.biotecnologia.com.br/revista/bio09/extracao.pdf>.

SCHIMITT, K. F. M.; SILVA, B. M.; ROSSI, A. A. B.; SANDER, N.; SILVA, C. J. Estabelecimento e otimização de protocolo para extração e amplificação de DNA em tecido foliar de Curcuma longa. (L). Enciclopédia Biosfera. v. 10, n. 19; p. 15601568, 2014. Disponível em < http://www.conhecer.org.br/enciclop/2014a/AGRARIAS/estabelecimento.pdf>.

SILVA, B. M.; DALBOSCO, E. Z.; BOTINI, N.; FARIA, R. B.; ROSSI, A. A. B. Protocolo para extração de DNA genômico de Anacardium giganteum W. Hancock ex Engl. (Anacardiaceae). Enciclopédia Biosfera. v. 10, n. 19; p. 2401- 2407, $2014 . \quad$ Disponível em < http://www.conhecer.org.br/enciclop/2014b/CIENCIAS\%20BIOLOGICAS/protocolo\% 20 para\%20extracao.pdf $>$.

SILVA, M. N. Extração de DNA genômico de tecidos foliares maduros de espécies nativas do cerrado. Revista Árvore. v. 34, n. 6, p. 973-978, 2010. Disponível em < http://www.scielo.br/pdf/rarv/v34n6/a02v34n6.pdf>.

SOBRAL, M.; PROENÇA, C.; SOUZA, M.; MAZINE, F.; LUCAS, E. Myrtaceae. In: Lista de Espécies da Flora do Brasil. Jardim Botânico do Rio de Janeiro. 2015. Disponível em <http://floradobrasil.jbrj.gov.br/> Acesso em: 28 mar. 2015.

ZUCCHI, M., I. Análise da estrutura genética de Eugenia dysenterica Dc utilizando marcadores RAPD e SSR. Tese (Doutorado em Agronomia) Universidade de São Paulo, Piracicaba, 2002. Disponível em: < file://C:/Users/Usuario/Downloads/maria\%20(2).pdf>. 